\title{
Does Imatinib Mesylate Therapy Cause Growth Hormone Deficiency?
}

\author{
L. Kebapcilara $\quad$ O. Bilgir ${ }^{b} \quad$ I. Alacacioglud $\quad$ B. Payzin ${ }^{d} \quad$ F. Bilgirc P. Oner ${ }^{c} \quad$ I. Saric \\ M. Calan ${ }^{c}$ O. Binicier ${ }^{\mathrm{e}}$ \\ ${ }^{a}$ Division of Endocrinology and Metabolism, ${ }^{b}$ Division of Hematology and ${ }^{c}$ Department of Internal Medicine, \\ Bozyaka Training and Research Hospital, d Division of Hematology, Department of Internal Medicine, Izmir Ataturk \\ Training and Research Hospital, and 'Department of Internal Medicine, Dokuz Eylul University, Izmir, Turkey
}

\section{Key Words}

Imatinib mesylate · Growth hormone deficiency •

Chronic myeloid leukemia

\begin{abstract}
Objective: The purpose of this study was to determine whether or not imatinib mesylate therapy induces growth hormone deficiency (GHD). Subjects and Methods: Seventeen patients with chronic myloid leukemia (CML) were enrolled in the study. The glucagon stimulation test (GST), and standard deviation scores (SDSs) of insulin-like growth factor 1 (IGF-I) and insulin-like growth factor binding protein (IGFBP-3) were used to determine GHD. The L-dopa test was performed on those with IGF-I SDSs above the -1.8 cut-off level. Results: Of the 17 patients in the study, 12 (70\%) had severe GHD (serum GH level $<3 \mu \mathrm{g} / \mathrm{l}$ after GST). IGF-I SDSs and IGFBP-3 SDSs were below -1.8 in 12 patients (70\%) and below -0.9 in 10 subjects (58\%). Four of the 5 remaining subjects with IGF-I SDS >-1.8 showed insufficient GH response to L-dopa stimulation. Nine subjects (52\%) had both severe GHD based on GST response and IGF-I SDS below -1.8. If an IGF-I SDS cut-off value $\mathrm{K}<-3$ were used, 5 out of 17 subjects (30\%) would be classified as GH deficient. These same pa-
\end{abstract}

\section{KARGER}

Fax +4161306 1234

E-Mail karger@karger.ch

www.karger.com
(C) 2009 S. Karger AG, Basel

1011-7571/09/0185-0360\$26.00/0

Accessible online at:

www.karger.com/mpp tients also showed severe GHD based on GST response. Conclusions: The data showed that a large number of patients on imatinib mesylate therapy had GH deficiency. A study involving a larger number of patients with a matched control group is needed to confirm the present observations.

Copyright $\odot 2009$ S. Karger AG, Basel

\section{Introduction}

The BCR-ABL gene tyrosine kinase (TK) inhibitor, imatinib, is an effective treatment agent in patients with chronic myloid leukemia (CML) [1]. TK is essential in the hypophysis for the secretion and action of growth hormone $(\mathrm{GH})[2,3]$. Activation of the $\mathrm{GH}$ releasing hormone $(\mathrm{GHRH})$ receptor in somatotropes is primarily linked to the adenylate cyclase signaling pathway leading to cAMP accumulation and activation of protein kinase A, protein kinase $\mathrm{C}$, TK [3] and extracellular $\mathrm{Ca}^{2+}$ entry through voltage-sensitive $\mathrm{Ca}^{2+}$ channels [3]. Chronic fatigue is a common and unexplained side effect of imatinib mesylate. In that context, the present study was undertaken to examine the effect of imatinib mesylate on $\mathrm{GH}$ secretion in CML subjects. 


\section{Subjects and Methods}

Seventeen patients were included in the study (11 males and 6 females; age, $47.52 \pm 9.76$ years; range, $29-61$ years). Exclusion criteria were as follows: history of diabetes mellitus, hypothyroidism, blastic transformation, previous CNS irradiation, impaired hepatic synthesis capacity (based on serum albumin levels and alanine aminotransferase, aspartate aminotransferase concentrations) and marked adrenal failure (9-hour cortisol $<100 \mathrm{nmol} / \mathrm{l})$. The study protocol was approved by the ethical committee, and informed consent was obtained from each patient. All female patients were postmenopausal. The imatinib treatment duration (time interval between the initiation and last doses of imatinib) was $38.47 \pm 19.83$ months (range: 3-71 months). Basal GH levels, insulin-like growth factor 1 (IGF-I), insulin-like growth factor binding protein (IGFBP-3) and peak GH level after stimulation tests (glucagon and L-dopa) were measured. For all measurements, fasting samples were collected in the morning.

\section{Measurements of GH, IGF-I and IGFBP-3}

IGF-I, IGFBP-3, and GH levels were determined using a chemiluminescent enzyme immunoassay with the Immulite Analyzer (Immulite 2000, Diagnostic Product Corporation, Los Angeles, Calif., USA). The intra- and interassay variation coefficients regarding IGF-I, IGFBP-3 and GH were 2.3-3.9, 3.7-8.1; 4.6-6, 6.89.5 and 3.80 and $6.40 \%$, respectively.

\section{Glucagon Stimulation and L-DOPA Tests}

The glucagon stimulation test (GST) was performed after administration of glucagon (i.m. $1 \mathrm{mg} ; 1.5 \mathrm{mg}$ if $>90 \mathrm{~kg}$ ) and serum GH levels were measured after 30,60, 90, 120, 150 and $180 \mathrm{~min}$ as previously described. L-Dopa was given at the dose of $500 \mathrm{mg}$, p.o., and serum GH levels were measured after 30, 60, 90, 120, 150 and $180 \mathrm{~min}[4]$.

\section{Calculation of Standard Deviation Scores}

IGF-1 and IGFBP-3 data were expressed as standard deviation scores SDSs for age and gender compared with normative data provided by the kit manufacturer (Immulite). Healthy adults ( $\mathrm{n}=$ 706) had been analyzed to obtain age-related normative ranges (Adult references ranges in Immulite kit). Each patient's IGF-1 and IGFBP-3 values and age and gender normative ranges (Immulite) were logarithmically transformed. The values were converted into SDSs using the corresponding reference values (adults) according to the following formula: $\mathrm{x}$ - average $\mathrm{x} / \mathrm{SD}$, where $\mathrm{x}$ is the actual log IGF-I or log IGFBP-3 of the patient, average $\mathrm{x}$ is the mean log IGF-I or log IGFBP-3 at the age in adults, and SD is the $\mathrm{SD}$ of the mean [5].

\section{Definition of GH Deficiency}

The following parameters were used to define GH deficiency (GHD): (1) GH level with a peak value of $<3.0 \mu \mathrm{g} / \mathrm{l}$ after GST [6]; (2) IGF-I and IGFBP-3 SDS below -1.8 and -0.9 , respectively, with $88 \%$ diagnostic efficiency [5]; (3) IGF-I SDS below -3 in adults over age 28 with $94 \%$ specificity [7]; (4) GH level with a peak value below $1.1 \mu \mathrm{g} / \mathrm{l}$ in patients after the L-dopa stimulation test [4]. The L-dopa test was carried out on patients who had basal IGF-I SDS levels above -1.8 .

Growth Hormone Deficiency Caused by Imatinib Mesylate
Statistical Analysis

Descriptive statistical analysis was performed using frequencies and percentages. The Spearman $\rho$ correlation was used to determine relationships between parameters. The statistical analysis was carried out using Statistical Package of Social Science, version 13.0. $\mathrm{p}<0.05$ was considered as statistically significant.

\section{Results}

\section{IGF-SDS, IGFBP-3-SDS and L-Dopa Test}

IGF-I SD and IGFBP-3 SDSs were below -1.8 in 12 patients, 7 males $/ 5$ females (70\%) and below -0.9 in 10 subjects, 6 males and 4 females (58\%), respectively. The Ldopa test was performed on patients who had basal IGF-I level SDSs higher than the cut-off value of -1.8 . Of the 5 patients tested with L-dopa, 1 achieved a $\mathrm{GH}$ peak response of $2.2 \mathrm{ng} / \mathrm{ml}$ (basal level $0.41 \mathrm{ng} / \mathrm{ml}$ ) $2 \mathrm{~h}$ after receiving L-dopa. Four patients did not have adequate peak $\mathrm{GH}$ values (mean basal: $0.26 \mathrm{ng} / \mathrm{ml}$; mean peak: $0.90 \mathrm{ng} /$ $\mathrm{ml}$; range: $0.020-0.935 \mathrm{ng} / \mathrm{ml})$.

\section{IGF-SDS and GST}

A GST was performed on all subjects and GH levels were determined. There were 12 patients (70\%; 8 males $/ 4$ females) with severe GHD (serum GH level $<3 \mu \mathrm{g} / \mathrm{l}$ ). Nine subjects (52\%) had severe GHD based on GST response with IGF-I SDSs below -1.8 . When a cut-off value of IGF-I SDS of less than -3 was taken, 5 out of 17 subjects had GHD. The subjects who had IGF-I SDSs below -3 also showed severe GHD based on GST response (table 1).

\section{Correlations}

There were no correlations with peak IGF-I values and imatinib treatment duration $(\mathrm{p}>0.05)$. On the other hand, IGF-I levels were positively correlated with IGFBP3 levels, IGF-I SDSs, IGFBP-3 SDSs $(\mathrm{p}<0.000, \mathrm{r}=0.87$; $\mathrm{p}=0.000, \mathrm{r}=0.90 ; \mathrm{p}=0.000, \mathrm{r}=0.89$, respectively) and inversely with age $(r=-0.64, p=0.006)$.

\section{Discussion}

The present study showed that $25-70 \%$ of the CML patients who were treated with imatinib mesylate exhibited GHD. According to two reliable tests, IGF-I SDSs and IGFBP-3 SDSs, $58-70 \%$ of this group had GHD. IGFBP-3 alone has a poor sensitivity in detecting patients with GHD and offers no diagnostic advantage over IGF-I. IGF-I levels are a valuable biochemical marker of GH se- 
Table 1. Clinical and laboratory parameters of the study group

\begin{tabular}{|c|c|c|c|c|c|c|c|c|c|c|c|}
\hline $\begin{array}{l}\mathrm{Pa}- \\
\text { tient }\end{array}$ & Sex & $\begin{array}{l}\text { Age } \\
\text { years }\end{array}$ & BMI & $\begin{array}{l}\text { IGF-I } \\
\mathrm{ng} / \mathrm{ml}\end{array}$ & $\begin{array}{l}\text { IGF-I } \\
\text { SDS }\end{array}$ & $\begin{array}{l}\text { IGFBP-3 } \\
\mathrm{ng} / \mathrm{ml}\end{array}$ & $\begin{array}{l}\text { IGFBP-3 } \\
\text { SDS }\end{array}$ & $\begin{array}{l}\text { Basal GH } \\
\mu \mathrm{g} / \mathrm{l} \text { for } \\
\text { GST }\end{array}$ & $\begin{array}{l}\text { Peak GH } \\
\mu \mathrm{g} / \mathrm{l} \text { for } \\
\text { GST }\end{array}$ & $\begin{array}{l}\text { Peak GH } \\
\mu \mathrm{g} / \mathrm{l} \text { for } \\
\mathrm{L} \text {-dopa }\end{array}$ & $\begin{array}{l}\text { Imatinib } \\
\text { treatment } \\
\text { months }\end{array}$ \\
\hline 1 & $\mathrm{M}$ & 35 & 23.73 & 187 & -0.26 & 5.65 & 0.1 & 0.78 & 7 & 0.918 & 60 \\
\hline 2 & $\mathrm{M}$ & 52 & 29.39 & 86.4 & -1.50 & 3.71 & -0.4 & 0.01 & 0.07 & 0.935 & 29 \\
\hline 3 & $\mathrm{M}$ & 61 & 27.78 & 50 & -2.17 & 1.85 & -1.38 & 0.020 & 2.81 & NA & 36 \\
\hline 4 & M & 29 & 27.75 & 83.8 & -2.15 & 3.71 & -0.50 & 0.02 & 0.285 & NA & 3 \\
\hline 5 & $\mathrm{M}$ & 51 & 33.2 & 106 & -1.0 & 3.12 & -0.71 & 0.025 & 1.06 & 0.883 & 61 \\
\hline 6 & M & 54 & 30.79 & 55.8 & -2.5 & 2.35 & -1.03 & 0.016 & 4.2 & NA & 71 \\
\hline 7 & $\mathrm{~F}$ & 46 & 29.35 & 76.7 & -1.87 & 2.94 & -0.74 & 0.12 & 4.89 & NA & 42 \\
\hline 8 & $\mathrm{M}$ & 61 & 25 & 42.7 & -3.05 & 2.39 & -1.03 & 0.082 & 1.96 & NA & 60 \\
\hline 9 & $\mathrm{~F}$ & 41 & 22.3 & 57.8 & -3.1 & 1.81 & -1.3 & 0.043 & 0.5 & NA & 58 \\
\hline 10 & $\mathrm{M}$ & 58 & 21.05 & 46 & -3.01 & 1.65 & -1.54 & 0.66 & 2.35 & NA & 49 \\
\hline 11 & $\mathrm{~F}$ & 49 & 28.82 & 51 & -2.54 & 1.9 & -1.35 & 0.11 & 5.08 & NA & 32 \\
\hline 12 & M & 55 & 27.3 & 44.6 & -3.01 & 0.57 & -2.93 & 0.65 & 1.07 & NA & 13 \\
\hline 13 & $\mathrm{~F}$ & 52 & 35.29 & 68.1 & -2.05 & 2.57 & -0.94 & 2.35 & 2.7 & NA & 12 \\
\hline 14 & $\mathrm{~F}$ & 40 & 27.65 & 102 & -1.38 & 3.17 & -0.57 & 0.029 & 0.01 & 0.875 & 32 \\
\hline 15 & M & 43 & 21.24 & 92 & -1.50 & 2.99 & -0.66 & 0.041 & 3.38 & 2.2 & 48 \\
\hline 16 & $\mathrm{M}$ & 31 & 25.73 & 77.4 & -2.31 & 2.75 & -0.94 & 0.95 & 1.08 & NA & 24 \\
\hline 17 & $\mathrm{~F}$ & 50 & 28.34 & 40.6 & -3.31 & 1.74 & -1.45 & 0.072 & 0.49 & NA & 24 \\
\hline
\end{tabular}

cretion. However, it is recommended that the diagnosis of adult GHD be confirmed by a provocation test of GH release [6]. Nearly 70\% of these GHD patients showed severe deficiency on the GST. According to the two most reliable tests, IGF-I SDSs and IGFBP-3 SDSs, $58-70 \%$ of this group had GHD. Nine subjects (52\%) had severe GHD based on the GST response and IGF-I SDSs below -1.8. An L-dopa test was done on 5 patients with IGF-I SDSs of more than $-1.8: 4$ of these patients demonstrated peaks less than $1.1 \mu \mathrm{g} / \mathrm{l}$ (impaired response). Using a cutoff value of IGF-1 SDS of less than -3, 5 (30\%) out of 17 subjects had GHD. The subjects who had IGF-I SDSs below -3 also showed severe GHD by GST.

The clinical implications of GHD observed in this study group are not known. The issue of the direct or indirect effect of GH and IGF-I on the occurrence or recurrence of malignancy, especially in the case of GH therapy in patients with leukemia, is still unresolved. Pastural et al. [8] suggested a relationship between high levels of IGF and blastic crisis in CML patients. GH treatment is contraindicated in the presence of an active malignancy [9]. From that perspective, it may be speculated that the amelioration of GH and IGF levels induced by imatinib mesylate may protect from blastic transformation. One interesting finding of the present study is a lack of correlation between the duration of imatinib therapy and GHD.
This indicates that the impaired GH response in CML patients who were receiving imatinib mesylate was more closely related with the action of the drug than the duration of therapy. The duration varied considerably, i.e. from 3 to 71 months, whereas GHD appeared to occur rapidly.

A high percentage of GHD may result from chronic illness. However, Oliveira et al. [10] showed that subjects with CML do not have depressed GH production. Studies directly comparing results from different assays in the same clinical samples in one laboratory confirmed disagreement between methods for assessing IGF [11]. Boquete et al. [5] applied Nichols RIA method and these results are thought to be different from the Immulite assay results which we applied in our study. However, in a recent report by Granada et al. [12], it was demonstrated that these immunoassays display suitable analytical performance for serum IGF-I measurement.

This study has some major limitations, notably the small sample size and the absence of a matched control group. Another limitation is the lack of an insulin tolerance test (ITT), which is the gold standard for assessing the $\mathrm{GH}$ axis. In older patients ( $\mathrm{n}=9$, age $>50$ years) and subjects with chronic diseases prone to hypoglycemia, we did not use the ITT. More recently, research has shown that cardiotoxicity is an unanticipated side effect of inhi- 
bition of c-Abl by imatinib [13]. On the other hand, the combined administration of GHRH with arginine recommended by the consensus guidelines [6] was beyond the scope of the present study. Instead, we used other established and reliable methods, including the GST and the L-dopa test, and IGF-I SDSs and IGFBP-3 SDSs.

\section{Conclusion}

A high percentage of CML patients receiving imatinib mesylate showed GHD as evidenced by the GST and the L-dopa tests and SDSs. More elaborate studies, with larger numbers of patients and matched controls are needed to confirm this finding and its clinical significance.

\section{References}

$>1$ Deininger MW, Druker BJ: Specific targeted therapy of chronic myelogenous leukemia with imatinib mesylate. Pharmacol Rev 2003;55:401-423.

2 Mayo KE, Miller T, DeAlmeida V, Godfrey P, Zheng J, Cunha SR: Regulation of the pituitary somatotroph cell by GHRH and its receptor. Recent Prog Horm Res 2000;55:266267.

$>3$ Anderson LL, Jeftinija S, Scanes CG: Growth hormone secretion: molecular and cellular mechanisms and in vivo approaches. Exp Biol Med (Maywood) 2004;229:291-302.

-4 Biller BM, Samuels MH, Zagar A, Cook DM, Arafah BM, Bonert V, Stavrou S, Kleinberg DL, Chipman JJ, Hartman ML: Sensitivity and specificity of six tests for the diagnosis of adult GH deficiency. J Clin Endocrinol Metab 2002;87:2067-2079.

$\checkmark 5$ Boquete HR, Sobrado PG, Fideleff HL, Sequera AM, Giaccio AV, Suárez MG, Ruibal GF, Miras M: Evaluation of diagnostic accuracy of insulin-like growth factor (IGF)-I and IGF-binding protein-3 in growth hormone-deficient children and adults using ROC plot analysis. J Clin Endocrinol Metab 2003;10:4702-4708.
6 Corneli G, Gasco V, Prodam F, Grottoli S, Aimaretti G, Ghigo E: Growth hormone levels in the diagnosis of growth hormone deficiency in adulthood. Pituitary 2007;10:141149.

7 Kwan AY, Hartman ML: IGF-I measurements in the diagnosis of adult growth hor mone deficiency. Pituitary 2007;10:151-157.

$>8$ Pastural E, Takahashi N, Dong WF, Bainbridge $\mathrm{M}$, Hull A, Pearson D, Huang S, Lowsky R, DeCoteau JF, Geyer CR. RIZ1 repression is associated with insulin-like growth factor-1 signaling activation in chronic myeloid leukemia cell lines. Oncogene 2007;26:1586-1594.

$\checkmark 9$ Molitch ME, Clemmons DR, Malozowski S, Merriam GR, Shalet SM, Vance ML, Stephens PA: Evaluation and treatment of adult growth hormone deficiency: an Endocrine Society Clinical Practice Guideline. J Clin Endocrinol Metab 2006;91:1621-1634.
10 Oliveira MR, Ohnuma L, Bendit I, DorlhiacLacer P, Giannella-Neto D: Interferon- $\alpha$ therapy increases type I insulin-like growth factor receptors expression on lymphoid cells from patients with chronic myelogenous leukemia. Leuk Res 2001;25:711-717.

11 Celniker AC, Chen AB, Wert RM Jr, Sherman BM: Variability in the quantitation of circulating growth hormone using commercial immunoassays. J Clin Endocrinol Metab 1989;68:469-476.

12 Granada ML, Ulied A, Casanueva FF, Pico A, Lucas T, Torres E, Sanmartí A: Serum IGF-I measured by four different immunoassays in patients with adult GH deficiency or acromegaly and in a control population. Clin Endocrinol (Oxf) 2008;68:942-950.

13 Kerkelä R, Grazette L, Yacobi R, Iliescu C, Patten R, Beahm C, Walters B, Shevtsov S, Pesant S, Clubb FJ, Rosenzweig A, Salomon RN, Van Etten RA, Alroy J, Durand JB, Force $\mathrm{T}$ : Cardiotoxicity of the cancer therapeutic agent imatinib mesylate. Nat Med 2006;12: 908-916. 